\title{
Multiple Myeloma with Plasmacytoma of the Lung - A Rare Entity
}

\author{
Rajashish Chakrabortty ${ }^{*}$, Susanta Kumar Paul ${ }^{2}$, Abir Hasan Dip ${ }^{3}$, Samia Rahman ${ }^{4}$, Shipon Chandra Paul ${ }^{5}$, Shah \\ Ashiqur Rahman Ashiq Choudhury6, Samprity Islam
}

\begin{abstract}
:
Multiple myeloma is a malignant proliferation of plasma cells that typically presents in the bone marrow. Extramedullary plasmacytoma (EMP) represents an unusual and characteristically progressive malignancy that can arise outside the bone marrow. The occurrence of multiple myeloma with plasmacytoma of the lung is very unusual. Herein, we report a case of multiple myeloma with plasmacytoma of the lung diagnosed by CT-guided FNAC and bone marrow trephine biopsy.
\end{abstract}

Keywords- Multiple myeloma, Extramedullary plasmacytoma, Trephine biopsy

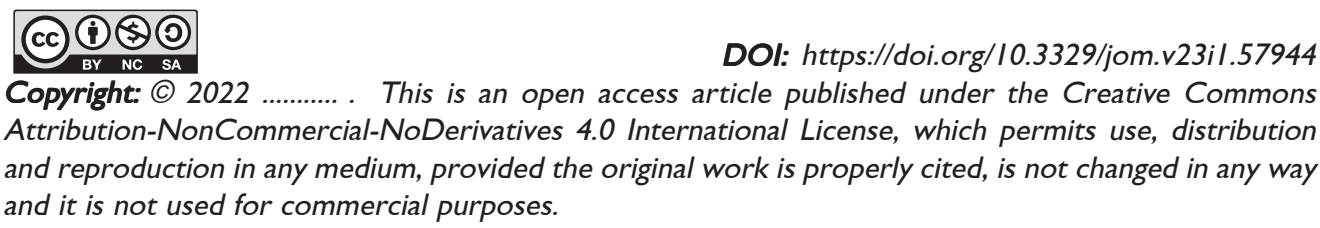

Received: 12 November, 202I;

Accepted: 13 November, 2021

\section{Introduction}

Multiple myeloma (MM) is a neoplastic proliferation of plasma cells that originated from a single clone. Although it is mainly involved in the bone marrow, a small percentage of plasma cells tumors arise outside the bone marrow termed extramedullary plasmacytoma. ${ }^{1}$ The tumor itself, its products, and host immune response against it cause various organ damage, and symptoms including bone pain, fracture, anemia, renal impairment, prone to infection, hypercalcemia, and occasional clotting abnormality, neurological symptoms, and features of hyperviscosity syndrome. It is documented that solitary plasmacytoma of bone or soft tissue can be the early presentation of multiple myeloma. Multiple myeloma with plasmacytoma of the lung is exceptionally rare to see with an average age of 60 years $^{2}$.

1. Associate Professor, Department of Respiratory Medicine, BSMMU, Dhaka

2. Phase-B Resident (Pulmonology), Department of Respiratory Medicine, BSMMU, Dhaka.

3. Phase-B Resident (Pulmonology), Department of Respiratory Medicine, BSMMU, Dhaka

4. Phase-B Resident (Pulmonology), Department of Respiratory Medicine, BSMMU, Dhaka

5. Phase-B Resident, Department of Respiratory Medicine, BSMMU, Dhaka, Bangladesh

6. Phase-B Resident, Department of Respiratory Medicine, BSMMU, Dhaka, Bangladesh

7. Assistant Professor of Respiratory Medicine, BSMMU, Dhaka Bangladesh

*Corresponding author: Dr. Rajashish Chakrabortty, Address: Apartment-1406, Block-A, Motalib Plaza Apartment Complex, 8/ 3, Paribag, Dhaka-1000, Bangladesh.E-mail: drrajashish@gmail.com
Here, we report a case of multiple myeloma with plasmacytoma of the lung in a 55-year-old, normotensive, nondiabetic, female, admitted in BSMMU.

\section{Case history:}

A 55-year-old, normotensive, nondiabetic, post-menopausal patient admitted to the Department of Respiratory Medicine with the complaints of chest pain for six months, fever and cough for seven days. Chest pain was insidious, progressive, non-radiating, and non-ischemic in nature, moderate in intensity, aggravated on movement, and partial response with painkiller. Fever was low grade, intermittent without any definite pattern. The highest recorded temperature was $101^{\circ} \mathrm{F}$. Cough was mostly dry, and occasionally scanty, mucoid, non-foul smelling sputum production, without any wheeze or hemoptysis. Cough was not aggravated on exposure to dust, cold air, or allergen. She had no family history of bronchial asthma. She denied any history of breathlessness, palpitation, paroxysmal nocturnal dyspnea, orthopnea, unilateral or bilateral leg swelling, contact with smear-positive tuberculosis patients. She had no history of frequency, urgency or dysuria, joint pain, rash, headache, blurring of vision, neck rigidity or unconsciousness. She was a mother of two daughters and one son. Her son died one year back due to acute leukemia. On general examination, the patient was mildly anemic, non-icteric, non-cyanosed, temperature $100^{\circ} \mathrm{F}$ with normal pulse and blood pressure. There was no koilonychia, leukonychia, clubbing, lymphadenopathy, and leg edema. On respiratory system examination, there was bilateral pleural effusion (Left $>$ Right). 
Laboratory investigations showed normal complete blood counts with low hemoglobin (Hb-9.8 g/dL). ESR was $68 \mathrm{~mm} /$ $1^{\text {st }}$ hour. Liver and renal functions were normal with normal serum electrolyte and calcium $(8.6 \mathrm{mg} / \mathrm{dL})$ levels. Cardiac markers like troponin I, pro-BNP, lactate dehydrogenase (LDH) was normal. Sputum gram stain showed growth of acinetobacter species. Chest radiography showed cardiomegaly with bilateral ground-glass change and left pleural thickening. Color Doppler echocardiography was normal and RT-PCR for Covid-19 was negative. X-ray dorsal spine showed degenerative changes with partial collapse of multiple vertebra. Bone mineral density(BMD) showed osteopenia in the lumbar vertebra and right femoral neck ( $\mathrm{T}$ score -1.1). Computed tomography (CT) scan of the chest with contrast showed- extensive marrow infiltrative lesion involving multiple dorsal vertebra and multiple ribs of both sides of the chest associated with overlying soft tissue swelling at both sides of the chest wall (Figure 1). Left sided moderate and right sided mild pleural effusion, collapse, and consolidation at the basal segment of the lower lobe of the left lung. Keeping in mind multiple myeloma and metastatic disease as a differential diagnosis, urine for Bence-Jones protein, plasma protein electrophoresis, pleural fluid aspiration, and study, bone marrow examination, and tumor markers were done. Urine for Bence-Jones protein was absent. Protein electrophoresis showed bisalbuminaemia (figure 2). Tumors markers were within normal range. The pleural fluid study showed lymphocyte predominant $(65 \%)$ transudative (protein $27 \mathrm{~g} / \mathrm{L}$ ) in nature with normal ADA. CT guided FNA from dorsal $7^{\text {th }}$ vertebrae body and left $10^{\text {th }}$ posterior rib and showed features of chronic discitis and negative for malignant cell. Bone marrow study showed myeloid and megakaryocytic hyperplasia. Then we planned for CT-guided FNA from the left lung mass, trephine bone biopsy, and immunofixation electrophoresis. CT-guided FNA from the left lung mass showed positive for malignant cells suggestive of plasmacytoma. Trephine bone biopsy showed favors plasmacytoma, and Immunofixation showed IgG Lambda(Figure 3).

Further workup revealed decreased hemoglobin (Hb-8.7 g/ $\mathrm{dl})$, increased serum creatinine $(2.70 \mathrm{mg} / \mathrm{dl})$, and serum calcium $(10 \mathrm{mg} / \mathrm{dl})$ with normal levels of serum albumin, lactate dehydrogenase, and uric acid. Left-sided thoracostomy was performed due to massive pleural effusion causing shortness of breath and fall of oxygen saturation. Then the patient partially improved of shortness of breath. Following that the first cycle of chemotherapy with bortezomib, melphalan, and dexamethasone was started, but, the patient developed severe hypoxia ( $\mathrm{SpO} 272 \%$ at ambient air), and saturation was not maintained up to $15 \mathrm{litre} / \mathrm{min}$ oxygen by non-rebreathing mask. Therefore, the patient was transferred to the intensive care unit for further management. After correction of hypoxia, the patient was referred to the Department of Palliative Medicine, and 3 days after patient was died.

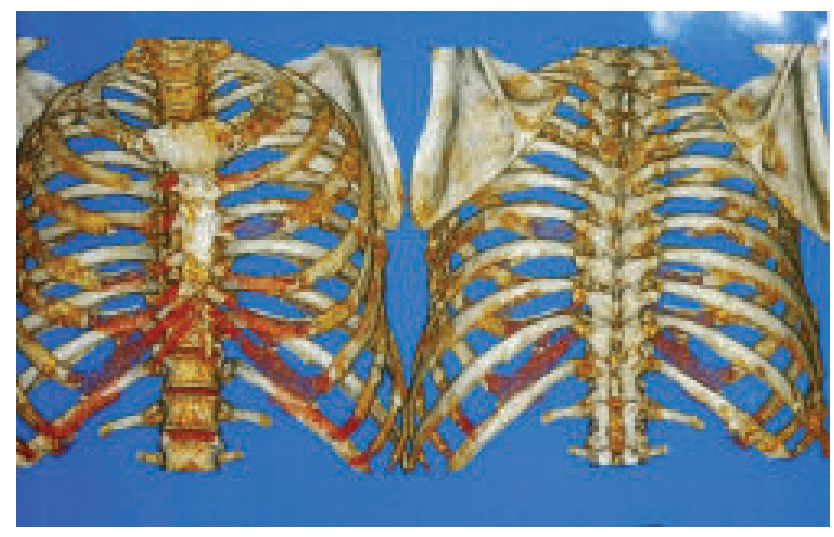

Figure 1: $3 D$ construction view of HRCT scan of the chest showing-marrow infiltrative lesion in the multiple dorsal vertebrae and multiple ribs of both sides of the chest

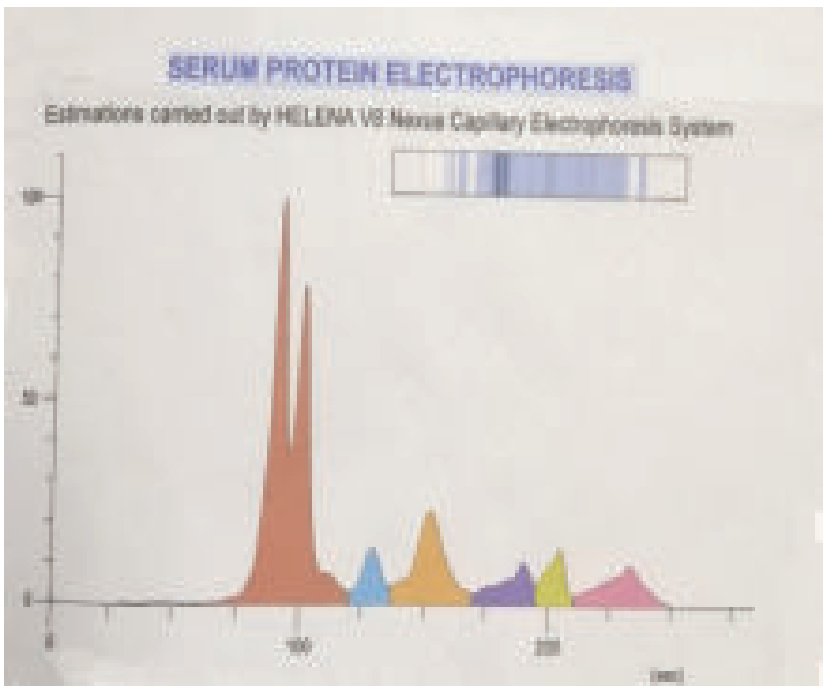

Figure 2: Serum Protein Electrophoresis showing Bisalbuminaemia

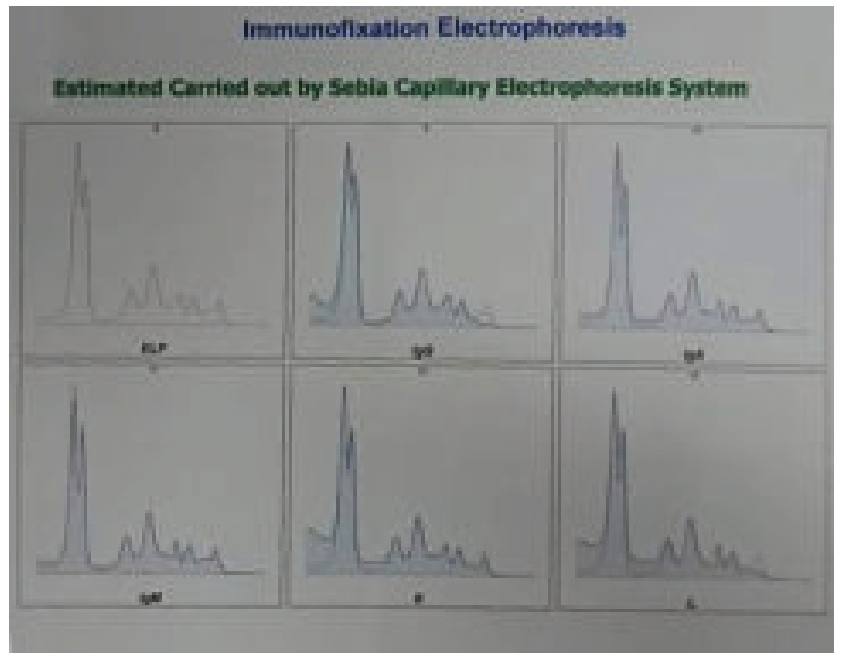

Figure 3: Immunofixation Electrophoresis showing- IgG lamda 
Table 1: Comparison of pulmonary manifestations in multiple myeloma as described in various authors

\begin{tabular}{|c|c|c|c|c|c|c|c|c|}
\hline & $\begin{array}{c}\text { Damoj et al } \\
(16)\end{array}$ & $\begin{array}{c}\text { Shin et al. } \\
\text { (10) }\end{array}$ & $\begin{array}{c}\text { Oymak et al. } \\
(17)\end{array}$ & $\begin{array}{c}\text { Duggal et } \\
\text { al.(18) }\end{array}$ & $\begin{array}{l}\text { Sullivan } \\
\text { et al. (5) }\end{array}$ & $\begin{array}{c}\text { Koss et al } \\
\text { (19) }\end{array}$ & $\begin{array}{c}\text { Prasad et } \\
\text { al.(20) }\end{array}$ & Present case \\
\hline Type & $\begin{array}{c}\text { Prospective } \\
\text { study }\end{array}$ & $\begin{array}{l}\text { Case } \\
\text { report }\end{array}$ & $\begin{array}{c}\text { Prospective } \\
\text { study }\end{array}$ & Case r & $\begin{array}{l}\text { Case } \\
\text { report }\end{array}$ & $\begin{array}{l}\text { Case } \\
\text { report }\end{array}$ & $\begin{array}{l}\text { Case } \\
\text { report }\end{array}$ & Cas \\
\hline Cases (n) & $\begin{array}{c}432 \text { (only } 11 \\
\text { had lung } \\
\text { manifestations) }\end{array}$ & 2 & $\begin{array}{l}38 \text { (only } 13 \text { had } \\
\text { lung } \\
\text { manifestations) }\end{array}$ & 1 & 1 & 5 & 1 & 1 \\
\hline $\begin{array}{c}\text { Age } \\
\text { (yrs)/sex }\end{array}$ & $\begin{array}{l}39-79 \\
8 \mathrm{M} / 3 \mathrm{~F}\end{array}$ & $\begin{array}{l}71 / \mathrm{M} \\
68 / \mathrm{F}\end{array}$ & $\begin{array}{c}40-80 \\
25 \mathrm{M} / 13 \mathrm{~F}\end{array}$ & $60 / \mathrm{M}$ & $51 / \mathrm{M}$ & $\begin{array}{l}50-79 \\
4 \mathrm{M} / 1 \mathrm{~F}\end{array}$ & $60 / \mathrm{M}$ & $55 / \mathrm{F}$ \\
\hline $\begin{array}{l}\text { Chest } \\
\text { radiology }\end{array}$ & $\begin{array}{l}\text { Pleural } \\
\text { involvement } \\
(8) \\
\text { and } \\
\text { Lung } \\
\text { parenchyma } \\
\text { (3) }\end{array}$ & $\begin{array}{l}\text { Pulmonary } \\
\text { multiple } \\
\text { nodules }\end{array}$ & $\begin{array}{l}\text { Pneumonia } \\
(6), \\
\text { Interstitial } \\
\text { shadows(3), } \\
\text { Mass lesions } \\
(2), \\
\text { Multiple } \\
\text { nodules (2) }\end{array}$ & $\begin{array}{l}\text { Homogenous } \\
\text { opacity } \\
\text { upper+ mid- } \\
\text { zone of the } \\
\text { right lung } \\
\text { with the } \\
\text { erosion of } \\
\text { right } 6^{\text {th }} \text { rib }\end{array}$ & $\begin{array}{l}\text { Bilateral } \\
\text { hilar } \\
\text { lymph } \\
\text { node } \\
+ \\
\text { lung } \\
\text { nodule }\end{array}$ & $\begin{array}{l}\text { Hilar mass } \\
\text { in } 2 \text { cases } \\
\text { and } \\
\text { Intraparen } \\
\text { chymal } \\
\text { mass in } 3 \\
\text { cases }\end{array}$ & $\begin{array}{l}\text { Left upper } \\
\text { lobe mass } \\
\text { with an } \\
\text { osteolytic } \\
\text { lesion in } \\
\text { the right } 6^{\text {th }} \\
\text { rib and } \\
\text { body of the } \\
\text { thoracic } 7^{\text {th }} \\
\text { vertebrae }\end{array}$ & $\begin{array}{l}\text { Marrow infiltrative } \\
\text { lesion in multiple } \\
\text { dorsal vertebrae and } \\
\text { ribs on both sides of } \\
\text { the chest with } \\
\text { collapse, } \\
\text { consolidation of left } \\
\text { lower basal segment } \\
\text { and bilateral pleural } \\
\text { effusion(Left>Right) }\end{array}$ \\
\hline
\end{tabular}

\section{Discussion:}

Plasma cell neoplasm are divided into the following categories: multiple myeloma (bone marrow and other systemic involvements), solitary myeloma of bone (bone plasmacytoma), extramedullary (soft tissue) plasmacytoma, and plasmablastic sarcoma. ${ }^{3}$

In multiple myeloma, there is an abnormal infiltration of plasma cells within the bone marrow, which leads to the multifocal osteolytic lesion. MM accounts for $1 \%$ of cancers and $10 \%$ of hematological malignancies. ${ }^{4}$. Extramedullary plasmacytoma (EMP) is a monoclonal proliferation of plasma cells in soft tissue or an organ. But the association between multiple myeloma, solitary plasmacytoma of bone, and extramedullary plasmacytoma are not well described. ${ }^{5}$

Some authors describe these three disorders represent a diverse manifestation of the same disease. Others regard solitary plasmacytoma of bone as a rare manifestation of multiple myeloma. The diagnosis of extramedullary plasmacytoma should be regarded differently and restricted to the tumor that occurs outside the bone marrow and may infiltrate the nearby lymph nodes or cause distant metastasis. ${ }^{6}$
The etiology of multiple myeloma is unknown but radiation, exposure to different organic solvents, and chronic infectious disease process play a significant role to stimulate the reticuloendothelial system in plasma cell dyscrasias.

EMP constitutes $3 \%-5 \%$ of plasma cell tumors of which $80 \%$ occurs in the upper airway tract particularly in the oropharynx and paranasal sinuses. ${ }^{7}$ In the lower respiratory tract, plasmacytoma occurs in the trachea-bronchiolar tree, structures of the hilum, or rarely in the lung parenchyma. However, the relationship between multiple myeloma and lung parenchyma is very rare. Only $5 \%$ of patients with lung plasmacytoma have coexistent multiple myeloma. ${ }^{8}$

EMP affects males three to four times often than in females, with an average age of 55. However, one-third of patients with extramedullary plasmacytoma is under 50years old. ${ }^{9}$

The clinical presentation of multiple myeloma is non-specific and variable. The most common typical thoracic manifestation of multiple myeloma is the bony involvement of the thoracic cage. While other manifestations are single or multiple pulmonary nodules, ${ }^{10}$ lobar or segmental consolidation $^{11}$, mediastinal lymphadenopathy ${ }^{12}$, intrapulmonary mass lesions, reticulonodular shadows, 
interstitial pattern, and intrapulmonary calcification ${ }^{13}$, pleural effusion with pleural thickening ${ }^{14}$, trachea-bronchiolar infiltration $^{15}$. Pulmonary manifestations in multiple myeloma as reported by various authors are given in table 1 .

In our patient, we made the diagnosis of plasmacytoma of lung, based on CT guided FNA finding from lung lesion as well as multiple myeloma by: (1) bone marrow trephine biopsyplasma cells, (2) myeloma-related organ or tissue impairment (hypercalcemia, serum creatinine $2.70 \mathrm{mg} / \mathrm{dl}$, hemoglobin $8.7 \mathrm{~g} /$ $\mathrm{dl}$, and lytic lesion in the multiple dorsal vertebrae and ribs), and (3) the presence of IgG lambda in immunofixation electrophoresis.

The protein electrophoresis in our patient showed bisalbuminemia. Bisalbuminaemia is a rare condition associated with two distinct bands in the albumin region seen on serum protein electrophoresis due to differences in their mobility. The prevalence of bisalbuminemia between $1: 1000$ to $1: 10000(21)$. It either can be inherited (autosomal dominant), or acquired. Bisalbuminaemia is seen in association with multiple myeloma, sarcoidosis, nephritic syndrome, chronic kidney disease, diabetes mellitus, Alzheimer's disease, pancreatic pseudocyst, and in patients who received high dose penicillin ${ }^{22}$. Bisalbuminemia may make difficult the diagnosis because of the misinterpretation of the extra band of albumin variant. Serum protein electrophoresis shows two distinct bands in the albumin region due to fast and slow-moving variants of albumin. For solving these conditions, immunofixation electrophoresis is required. though, bisalbuminemia interferes with the diagnosis of serum electrophoresis but does not influence the disease progression or management. ${ }^{23}$

After the diagnosis of plasmacytoma, extensive investigation for multiple myeloma is crucial, as the treatment is completely different for both types of plasma cell disorders. Plasmacytoma are treated with radiotherapy, surgery, or both. $^{24}$.

Treatment of multiple myeloma depends on patients' age and prognostic factors. Despite the advancement in treatment, multiple myeloma remains an incurable disease until now. Regardless of the treatment regimen or initial response to treatment, the disease follows a high relapsing rate in the majority of the patients. Induction and maintenance therapy are two key steps in the management of newly diagnosed multiple myeloma patients. Induction therapy should initiate immediately following diagnosis and maintenance therapy, a long-term treatment that patients often are given after induction therapy, and (usually) a stem cell transplant. According to the 2020 National Comprehensive Cancer Network (NCCN) Multiple Myeloma guidelines, therapy for multiple myeloma should consist of $\left({ }^{3}\right)$ a combination of bortezomib/dexamethasone/lenalidomide or thalidomide as primary induction therapy for autologous stem cell transplant candidates. Cyclophosphamide or doxorubicin might be alternative. $\left({ }^{33}\right)$ a combination of melphalan/prednisone/ lenalidomide or bortezomib as primary induction therapy for non-transplant candidates. The preferred maintenance therapy for autologous stem cell therapy is lenalidomide. Other maintenance options are ixazomib or bortezomib but in certain high-risk cases, bortezomib plus lenalidomide with or without dexamethasone is used ${ }^{24}$. Patients who have a relapse after initial disease control may be treating with any of the agents not already utilized. If the multiple myeloma relapse occurs longer than six months after the initial therapy, then the initial regimen can be used again.

The differential diagnoses of multiple myeloma are metastatic carcinoma, bone neoplasm, lymphoma, and chronic lymphocytic leukemia ${ }^{14}$.

\section{Conclusion:}

Multiple myeloma with plasmacytoma is a rare entity and carries a bad prognosis. Therefore, when an older patient presents with a bony lesion, multiple myeloma should be kept in mind as a differential diagnosis. This case is unique in the presentation of plasmacytoma of the lung and negative results in the initial investigation for multiple myeloma

\section{References:}

1. Saha K, Sit NK, Maji A, Jash D. A case of multiple myeloma with lung involvement. Middle East J Cancer. 2012;3(3):758 .

2. Dimopoulos MA, Kiamouris C, Moulopoulos LA. Solitary plasmacytoma of bone and extramedullary plasmacytoma. Hematol Oncol Clin North Am. 1999;13(6):1249-57.

3. Kutluk AC, Kocatürk CÝ, Seyrek Y, Fener NA. Extramedullary plasmacytoma: report of a case manifested as a pleural mass. Curr Thorac Surg. 2017;2(3):96-9.

4. Nipu M, Cri'an E, Olteanu M, Cãlãra ${ }^{\circ} u$ C, Olteanu M, Popescu MR. Lung Involvement in Multiple Myeloma Case Study. Curr Heal Sci J. 2014;40(4):274-6.

5. O'Sullivan P, Müller NL. Pulmonary and nodal multiple myeloma mimicking lymphoma. $\mathrm{Br} J$ Radiol. 2006;79(943):25-7.

6. Wiltshaw E. The natural history of extramedullary plasmacytoma and its relation to solitary myeloma of bone and myelomatosis. Medicine (Baltimore). 1976;55(3):21738.

7. Mukherjee B. Diagnostic Histopathology of Tumours. Med Journal, Armed Forces India. 2001;57(4):344-5. 
8. Rao MG, Venkatesh R. Radiological evaluation of extramedullary plasmacytoma. Kans Med. 1994;95(4):945 .

9. Galieni P, Cavo M, Avvisati G, Pulsoni A, Falbo R, Bonelli MA, et al. Solitary plasmacytoma of bone and extramedullary plasmacytoma: Two different entities? Ann Oncol. 1995;6(7):687-91.

10. Shin MS, Carcelen MF, Ho KJ. Diverse roentgenographic manifestations of the rare pulmonary involvement in myeloma. Chest. 1992;102(3):946-8.

11. Mohammad Taheri Z, Mohammadi F, Karbasi M, Seyfollahi L, Kahkoei S, Ghadiany M, et al. Primary pulmonary plasmacytoma with diffuse alveolar consolidation: a case report. Patholog Res Int. 2010; 2010:463-5.

12. Luh SP, Lai YS, Tsai CH, Tsao TCY. Extramedullary plasmacytoma (EMP): Report of a case manifested as a mediastinal mass and multiple pulmonary nodules and review of literature. World J Surg Oncol. 2007;5:123.

13. Kintzer JS, Rosenow EC, Kyle RA. Thoracic and Pulmonary Abnormalities in Multiple Myeloma: A Review of 958 Cases. Arch Intern Med. 1978;138(5):727-30.

14. Kushwaha, Verma SK, Mehra S, Prasad R. Pulmonary and nodal multiple myeloma with a pleural effusion mimicking bronchogenic carcinoma. J Cancer Res Ther. 2009;5(4):297.

15. Shih LY, Dunn P, Leung WM, Chen WJ, Wang PN. Localised plasmacytomas in Taiwan: comparison between extramedullary plasmacytoma and solitary plasmacytoma of bone. Br J Cancer. 1995;71(1):128-33.

16. Damaj G, Mohty M, Vey N, Dincan E, Bouabdallah R, Faucher C, et al. Features of extramedullary and extraosseous multiple myeloma: a report of 19 patients from a single center. Eur J Haematol. 2004; 73(6):402-6.
17. Oymak FS, Karaman A, Soyuer I, Karaman H, Gülmez I, Demir R, et al. Pulmonary and chest wall involvement in multiple myeloma. Tuberk Toraks. 2003; 51(1):27-32.

18. Duggal RK, Ramachandran KA. Multiple myeloma with extra-medullary dissemination in the lung. JIACM. 2002;3(1):93-5.

19. Koss MN, Hochholzer L, Moran CA, Frizzera G. Pulmonary plasmacytomas: a clinicopathologic and immunohistochemical study of five cases. Ann Diagn Pathol. 1998;2(1):1-11.

20. Prasad R, Verma SK, Sodhi R. Multiple myeloma with lung plasmacytoma. Lung India. 2011;28(2):136-8.

21. Chan PC, Yasodhara A, Truong D. Bisalbuminemia: lack of association with monoclonal gammopathy and valuejustification for reporting in serum protein electrophoresis. $J$ Clin Chem Lab Med. 2017;1(1):1-4.

22. Agarwal P, Parkash A, Tejwani N, Mehta A. Bisalbuminemia: A rare finding on serum electrophoresis. Indian J Hematol blood Transfus. 2018;34(3):558-9.

23. Chhabra S, Bansal F, Saikia B, Minz RW. Bisalbuminemia: a rarely encountered protein anomaly. $J$ Lab Physicians. 2013;5(2):145-6.

24. Jyothirmayi R, Gangadharan VP, Nair MK, Rajan B. Radiotherapy in the treatment of solitary plasmacytoma. $\mathrm{Br}$ J Radiol. 1997;70(833):511-6.

25. Kumar SK, Callander NS, Adekola K, Anderson L, Baljevic M, Campagnaro E, et al. Multiple myeloma: clinical practice guidelines in oncology. J Natl Compr Canc Netw. 2020;18(12):1685-717. 